\title{
Closely related intertidal and deep-sea Halomonhystera species have distinct fatty acid compositions
}

\author{
Jelle Van Campenhout ${ }^{1,2^{*}}$ and Ann Vanreusel ${ }^{1}$
}

\begin{abstract}
The deep-sea free-living nematode Halomonhystera hermesi, dominant in the sulphidic sediments of the Håkon Mosby mud volcano (1280 m, Barent sea slope), is part of the mainly estuarine Halomonhystera disjuncta species complex consisting of five cryptic species (GD1-GD5). Cryptic species have a very similar morphology raising questions on their specific environmental differences. This study analyzed total fatty acid (FA) compositions of H. hermesi and GD1, one of $H$. hermesi's closest relatives. Additionally, we experimentally investigated the effect of a temperature reduction, salinity increase and sulphide concentrations on GD1's FA composition. Because nematodes are expected to have low amounts of storage FA, total FA compositions most likely reflect FA contents of cellular membranes. The deep-sea nematode $H$. hermesi had significantly lower saturation levels and increased highly unsaturated fatty acid (HUFAs) proportions due to the presence of docosahexanoic acid (DHA-22:6w3) and higher eicosapentaenoic acid (EPA-20:5 w3) proportions. HUFAs were absent in H. hermesi's food source indicating the ability and need for this nematode to synthesize HUFAs in a deep-sea environment. Our experimental data revealed that only a decrease in temperature resulted in lower saturated fatty acids proportions, indicating that the FA content of $\mathrm{H}$. hermesi is most likely a response to temperature but not to sulphide concentrations or salinity differences. In experimental nematodes, EPA proportions were low and DHA was absent indicating that other factors than temperature, salinity and sulphides mediate the presence of these HUFAs in H. hermesi.
\end{abstract}

Keywords: Nematodes, Deep sea, Halomonhystera, Fatty acids, DHA, Hakon mosby mud volcano

\section{Background}

Organisms require adaptive responses when presented to changes within their environment to survive and reproduce successfully. Environmental adaptation can result in morphological, physiological, behavioural or developmental differences. It is known that environmental changes can alter cell membrane fluidity, which could impede membrane function and stability, and performance of membrane-associated enzymes [61]. Cellular membranes function as a physiological barrier with a limited permeability and mainly consist of phospholipids, of which fatty acids are the most variable part

\footnotetext{
*Correspondence: jelle.ugent@gmail.com

${ }^{1}$ Research Group Marine Biology, Biology Department, Ghent University, Krijgslaan 281 S8, 9000 Ghent, Belgium

Full list of author information is available at the end of the article
}

[40]. It is, therefore, essential that the liquid-crystalline structure of the membrane is maintained by regulation of the FA composition to acclimatize cells to changing environmental conditions, as is evidenced from temperature effects in poikilotherms [28]. Alterations in the composition of membrane phospholipids in response to environmental changes are of critical importance for the function and integrity of cell membranes, and is a general phenomenon in animals, known as "homeoviscous adaptation" (HVA) or "homeophasic adaptation" [30, 39, 61].

Nematodes, one of the most numerous of all Metazoa in terms of species richness [41], exist in all habitats that can support life and demonstrate remarkable abilities to withstand stress and adverse conditions [44,62]. It has been suggested that marine nematodes do not accumulate lipids for energy storage [27] indicating that nematode fatty acid composition reflects membrane fatty acid 
composition, however, information remains scant. In this study we will focus on the marine free-living nematode Halomonhystera disjuncta (formerly known as Geomonhystera disjuncta), which is known for its high resistance to environmental stress, especially to heavy metals and temperature changes [25, 75-77]. H. disjuncta and sister species has been reported both in shallow-water $[15,47$, $74]$ and in deep-sea environments [53, 71]. Mitochondrial and nuclear DNA sequences as well as morphometric analysis revealed that $H$. disjuncta from the Western Scheldt and the North Sea actually consist of five cryptic species (GD1-GD5) [15] with nearly imperceptible morphometric differences [22]. The same marine nematode has been morphologically identified as the dominant nematode species at the sulphide rich bacterial mats of two methane cold seeps: the Nyegga pockmarks (Nordic Norwegian margin, 730 m water depth) [53] and Håkon Mosby mud volcano (HMMV, Barents Sea slope, $1280 \mathrm{~m}$ water depth) [71]. The HMMV relative is closely related to the intertidal Halomonhystera cryptic species complex but can be distinguished from its shallow-water relatives both morphometrically and with the use of genetic markers [69], and was, therefore, described as a new species named $H$. hermesi [64]. Phylogenetic relationships showed that $H$. hermesi is most closely related to GD1 and GD4. Interestingly, GD1 appeared to be more resistant to simulated cold seep conditions compared to GD2-GD3 [68]. However, lack of any information on the biochemical resources (e.g. FA composition) hampers our understanding of the unique biology of closely related species in different environment.

The deep sea is a relatively harsh environment with constantly low ambient temperatures $\left(\sim 2{ }^{\circ} \mathrm{C}\right)$, high water pressure and absence of light. Furthermore, cold seeps are characterized by methane seepage through sediment and rely on chemosynthetically derived energy. They often have high concentrations of sulphides, as a result of microbial sulphate reduction coupled to anaerobic oxidation of methane [43]. Most studies on adaptive changes of the FA composition to deep-sea conditions have been performed on barotolerant bacteria under different experimental conditions and have revealed increased proportions of mono- and poly-unsaturated FAs in response to increased pressure and/or reduced temperature $[13,67,80]$. Consistent with bacterial responses, a comparison of mitochondrial membranes isolated from shallow and deep-sea fish species has identified similar changes in unsaturation levels [10, 73]. Moreover, highly unsaturated FAs (HUFAs) are believed to be essential in piezophilic adaptation of cellular membranes [81] and

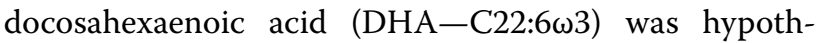
esized to be the key to HVAs to depth and temperature changes in vertically migrating planktonic copepods [52].
As such, we expect higher proportions of unsaturated fatty acids and HUFAs in H. hermesi compared to GD1.

The second part of this study consists of a comparison of the FA composition of GD1 nematodes under simulated estuarine and bathyal seep conditions. We investigated the effect of three abiotic factors salinity, temperature and sulphide on total fatty acid composition. Each of the three abiotic factors varied from control conditions (salinity of $25,16{ }^{\circ} \mathrm{C}$ and no sulphide) to environmental conditions representative of the HMMV (salinity of $34-35,-0.9^{\circ} \mathrm{C}$ and hydrogen sulphide concentrations up to $1 \mathrm{mM}$ ) [58, 72]. As previously mentioned, temperature decrease has a clear effect on the FA composition in cellular membranes resulting in an increase in the unsaturated fatty acid proportions. Such a response is uniform and we, therefore, anticipate similar outcomes. The effect of increased salinity, however, is an increase of saturated FA levels and decreased proportions of unsaturated FAs as described for the bacteria Shewanella [49] and Halomonas species [37], and several plant species from the Ephedra genus [3], but information remains scant. Moreover, salinity effects were also found to be opposite between different plant varieties of the same species [34]. Lastly, no information on the effects of sulphides on FA composition currently exists. We can, however, consider sulphides to be a toxic compound because $H$. disjuncta is unable to survive concentrations higher than $1.5 \mathrm{mM}$ (personal observations). In the presence of a toxic compound in sublethal concentrations, cells start to decrease membrane fluidity by increasing the degree of FA saturation $[17,48,60]$. The experimental data, discussed within this paper, allows investigating the individual effects of environmental factors on FA composition. In addition, it can aid in the correct interpretation of observed differences in FA composition between $H$. hermesi and GD1 sampled from the HMMV and Western Scheldt estuary, respectively.

\section{Methods Intertidal GD1 nematode cultures}

Decaying Fucus vesiculosus was collected from the Paulina tidal flat, located along the southern shore of the polyhaline zone of the Western Scheldt estuary (southwestern part of The Netherlands). Macroalgal pieces were transferred to Petri dishes containing $0.8 \%$ nutrient:bacto agar (ratio of 1/7) prepared in artificial seawater [46] with a salinity of 25 and placed at a constant temperature of $16{ }^{\circ} \mathrm{C}$. Two weeks after inoculation, one single gravid female was transferred to a new Petri dish $(5.5 \mathrm{~cm}$ inner diameter), containing the same agar medium, to establish monospecific GD1 cultures. Frozen-and-thawed Escherichia coli $\mathrm{K} 12$ was added as a food source and cultures were placed at a constant 
temperature of $16{ }^{\circ} \mathrm{C}$. Monospecificity and species identity were verified, shortly after inoculation, by PCR and sequencing the ITS gene. Primers and thermal-cycling conditions can be found in Derycke et al. [15].

\section{Sample collection}

Intertidal GD1 nematodes were harvested from the monospecific cultures and transferred to rehydrated (salinity of 25), defaunated $F$. vesiculosus $\left(48 \mathrm{~h}\right.$ at $60{ }^{\circ} \mathrm{C}$ ). They were allowed to grow for ca. 4 weeks in three litterbags (mesh size $200 \mu \mathrm{m}$ ) at $8{ }^{\circ} \mathrm{C}$ and a salinity of 25 . Litterbags were then placed at the Paulina tidal flat (Western Scheldt estuary, $51^{\circ} 20^{\prime} 56.79^{\prime \prime} \mathrm{N}, 3^{\circ} 43^{\prime} 29.56^{\prime \prime} \mathrm{E}$ ) for $72 \mathrm{~h}$. Following this period, macroalgae were washed over two stacked sieves (top sieve: $1 \mathrm{~mm}$, bottom sieve: $32 \mu \mathrm{m}$ ) and fauna was retained on the bottom sieve. The sieve was rinsed with sieved seawater $(32 \mu \mathrm{m})$ and replicate samples were frozen in liquid nitrogen and stored at $-80{ }^{\circ} \mathrm{C}$ awaiting further analysis. Throughout the rest of the study, GD1 samples extracted from the Paulina tidal flat, will be referred to as $\mathrm{GD} 1_{\mathrm{p}}$.

Deep-sea sediment samples were collected at the HMMV during the Maria S. Merian cruise 2010 using a TV-guided multi-corer. The microbial mats, the preferred habitat of $H$. hermesi, were selected and sampled from three locations (Station MSM16-2_802-1, 72 $0.17^{\prime} \mathrm{N}, 14^{\circ} 43.88^{\prime} \mathrm{E}$; Station MSM16-2_829-1, $72^{\circ} 0.16^{\prime} \mathrm{N}, 14^{\circ} 43.94^{\prime} \mathrm{E}$; Station MSM16$\left.2 \_831-1,72^{\circ} 0.14^{\prime} \mathrm{N} 14^{\circ} 43.94^{\prime} \mathrm{E}\right)$. Cores from these locations were immediately sliced on board from 0 to $10 \mathrm{~cm}$ with a one $\mathrm{cm}$ interval and samples for fatty acid composition were stored at $-80^{\circ} \mathrm{C}$.

\section{Nematode extraction}

The top $\mathrm{cm}$ of three deep-sea samples and part of the three intertidal samples, were thawed and nematodes were extracted by density gradient centrifugation, using Ludox (a colloidal silica polymer; specific gravity 1.18) as a flotation medium [31]. For each replicate, ca. 333 nematodes of each sex (male and female) and 333 juveniles were manually picked out using a binocular microscope to easily select Halomonhystera species based on their morphology. Per replicate, juveniles and adults were pooled to encompass all life stages and sexes present in the population. Nematodes were then rinsed twice in sterile Mili- $\mathrm{Q}$ for at least $1 \mathrm{~h}$ to remove most adhering bacteria and transferred to glass $5 \mathrm{ml} \mathrm{GC}$ vials in sterile Mili-Q and stored at $-80{ }^{\circ} \mathrm{C}$ prior to fatty acid extraction.

\section{GD1 experimental set up}

The effect of three abiotic factors (salinity, temperature and sulphide presence/absence) on fatty acid composition was tested by a replicated fully crossed design with three factors: a salinity of 25 and 34, temperatures of 16 and $4{ }^{\circ} \mathrm{C}$ and presence or absence of sulphide $(0$ and $1 \mathrm{mM})$. Because simulated cold deep-sea temperatures resulted in occasional crystallization of the agar medium, a temperature of $4{ }^{\circ} \mathrm{C}$ was used. Experimental control conditions were $16{ }^{\circ} \mathrm{C}$ and a salinity of 25 because stock cultures are maintained at these conditions. The experiment was conducted on experimental microcosms which consisted of Petri dishes $(5.5 \mathrm{~cm}$ i.d.) containing $1.5 \mathrm{ml}$ $0.8 \%$ nutrient:bacto agar (1/7). The sulphidic medium consisted of the same agar as described above to which we added sodium thiosulphate $\left(\mathrm{Na}_{2} \mathrm{~S}_{2} \mathrm{O}_{3}\right)$ and sodium sulphide $\left(\mathrm{Na}_{2} \mathrm{~S}\right)$ in a final concentration of $1 \mathrm{mM}$ for both reagents; $350 \mu \mathrm{l} \mathrm{E}$. coli $\mathrm{K} 12$ (ca. $8 \times 10^{8}$ cells $/ \mathrm{ml}$ ) was added as a food source, sufficient for the duration of the experiment. In addition, $350 \mu \mathrm{l}$ of the $E$. coli food source was also stored at $-80^{\circ} \mathrm{C}$ for further fatty acid analysis.

The experiment was started by manually picking out 60 females and 40 males $\left(\mathrm{F}_{0}\right)$ from the monospecific GD1 stock cultures which were deposited in the microcosms. Petri dishes were closed with parafilm and maintained in temperature-controlled incubators without light for the whole length of the experiment. Two days after the minimum generation times (9-11, 10-15 and 28-39 days at 16,10 and $4{ }^{\circ} \mathrm{C}$, respectively) [68], $333 \mathrm{~F}_{1}$ nematodes (111 juveniles, males and females) from each replicate were manually picked out and washed as described above. Because we required 1000 nematodes for further analysis and microcosms did not yield many nematodes, the replicate samples were pooled, frozen in $5 \mathrm{ml} \mathrm{GC}$ vials and stored at $-80^{\circ} \mathrm{C}$.

\section{Analytic techniques and data treatment}

Deep-sea, intertidal and experimental GD1 samples, and the $E$. coli food source were lyophilized for $24 \mathrm{~h}$ before extraction. Extraction and esterification of fatty acids was performed according to a modified one-step method of Abdulkadir and Tsuchiya [1]. Briefly, samples were mixed with $700 \mu \mathrm{l}$ of a $2.5 \% \mathrm{H}_{2} \mathrm{SO}_{4}$-methanol solution in a capped tube and heated at $80{ }^{\circ} \mathrm{C}$ for $90 \mathrm{~min}$. After cooling to room temperature, $350 \mu \mathrm{l}$ hexane and $350 \mu \mathrm{l}$ of a $0.95 \%$ $\mathrm{NaCl}$ solution were added. After stirring, samples were centrifuged for $10 \mathrm{~min}$ at $1000 \mathrm{rpm}(650 \mathrm{~g})$. Of the two phases which formed, the upper hexane layer, containing the fatty acid methyl esters (FAMEs), was transferred to a capped vial to be injected into the gas chromatographer (GC) for FAME analysis. Five microlitre of the FAMEs solution was injected on a HP88 column (Agilent J\&W) at a temperature of $250{ }^{\circ} \mathrm{C}$ and separated using gas chromatography (Hewlett Packard 6890N) coupled to a mass spectrometer (HP 5973) to obtain ion profiles for identifications. Oven temperatures were the same as described in De Troch et al. [12]. 
FAMEs identification was based on the comparison of the mass spectral fragmentation spectra and retention times to authentic standards and mass spectral libraries (WILEY and in-house libraries) using the MSD ChemStation software (Agilent Technologies). Linear regression of peak areas of external standards (Supelco \#47885, Sigma-Aldrich) in known concentrations ranging from 5 to $250 \mu \mathrm{g} \mathrm{ml}^{-1}$ were used for FAME quantification. The slope of the linear regression of the external standards and amount of hexane is employed to quantify each individual FAME according to De Troch et al. [12]. Ratios between individual FAME and C16:0 peak areas were determined and ratios $<0.02$ were deemed unreliable and, therefore, removed [16]. In addition, unassigned peaks were removed from the dataset. The nomenclature of the fatty acids follows the universal $\mathrm{X}: \mathrm{Y} \omega \mathrm{Z}$ form, were $\mathrm{X}$ represents the number of carbon atoms, $\mathrm{Y}$ equals the number of double bonds and $\mathrm{Z}$ gives the position of the double bond counting from the terminal methyl group [26]. Because we were unable to reliably distinguish isoforms and anteisoforms, these peaks, of each respective FA, were summed and "(ante)iso" was added to the universal $\mathrm{X}: \mathrm{Y} \omega \mathrm{Z}$ form throughout the rest of this paper. FAME concentrations were standardized to the total amount of nematodes added, resulting in pico grams per nematode. Because organisms have the ability for a genotype to match their phenotype to different environments which can influence the total amount of FAs under different experimental conditions, relative proportions of each quantified FAME to the total amount of pg fatty acids were determined. Similarly, relative FA proportions of the E. coli food source (added to experimental microcosms) were determined as described above.

\section{Statistical analysis on Halomonhystera hermesi and GD1 $1_{\mathrm{p}}$}

To test the difference in relative fatty composition between Halomonhystera hermesi and $\mathrm{GD} 1_{\mathrm{p}}$, a one factor permutational based multivariate analysis of variance [5], on the basis of Bray-Curtis similarity with 9999 permutations, was performed. The results were visualized by non-metric multidimensional scaling (MDS). Samples were clustered based on group average and a SIMPER analysis was used to identify which fatty acid accounted for the observed dissimilarity between species. PERMDISP [4] was executed to test the homogeneity of multivariate dispersions. Because of the limited level of replication, a Monte Carlo test was performed at all times and all $p$ values in this study have been FDR-corrected in $R$ version 3.0.2 [54].

Comparing relative proportions of FAs based upon the total fatty acid content between species might not truly reflect the composition of SFAs, MUFAs and PUFAs. Therefore, fatty acids were divided into three classes based on the saturation level: saturated fatty acids (SFAs), mono-unsaturated fatty acids (MUFAs) and poly-unsaturated fatty acids (PUFAs). The total values for each class are the sum of values for the following major components: SFAs (C12:0, C13:0, C14:0, (ante)isoC15:0, C15:0, (ante)isoC16:0, C16:0, (ante)isoC17:0, C17:0, C18:0,

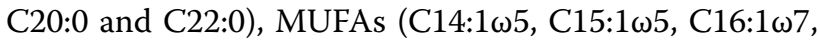
$\mathrm{C} 17: 1 \omega 7, \quad \mathrm{C} 18: 1 \omega 12, \quad \mathrm{C} 18: 1 \omega 9, \quad \mathrm{C} 18: 1 \omega 7, \quad \mathrm{C} 20: 1 \omega 9$,

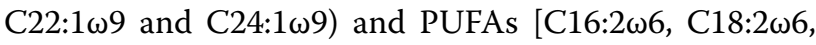
$\mathrm{C} 18: 3 \omega 3, \mathrm{C} 18: 3 \omega 6, \mathrm{C} 20: 2 \omega 6, \mathrm{C} 20: 3 \omega 6, \mathrm{C} 20: 4 \omega 6, \mathrm{c} 20: 5 \omega 3$

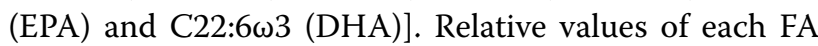
were determined based upon the total sum of its respective FA class. The difference in SFA-, MUFA- and PUFAcomposition, was statistically analysed as described above (Bray-Curtis similarity). The difference between both species of each FA proportion per class was determined using Euclidean distances with 9999 permutations and a PERMANOVA was performed.

In addition, PUFAs with a chain length $\geq 20$ carbons and $\geq 3$ double bonds, known as HUFAs, were summed, SFA/UFA ratio (with UFA defined as the sum of MUFA and PUFA) and the unsaturation index were determined. The unsaturation index is the sum of MUFA and PUFA proportions multiplied by the respective amount of unsaturated bonds of each respective FA. To test the difference between SFA/UFA ratios, unsaturation indices and HUFA proportions, Euclidean distances was used in PERMANOVA. All analyses were performed within PRIMER v6 with PERMANOVA+ add-on software [5]. Figures were made with Graphpad prism 5.

\section{Statistical analysis of the experiment (GD1)}

Relative proportions of FAs were determined in the same way as described above and the same parameters were calculated. We have performed a fully crossed PERMANOVA design with three fixed factors (on all parameters separately: total FA-, SFA-, MUFA-, PUFA- and HUFA-composition, SFA/UFA ratios and unsaturation indices). The three factors were temperature (16 and $4{ }^{\circ} \mathrm{C}$ ), salinity (25 and 34) and sulphide ( 0 and $1 \mathrm{mM}$ ). Because we lack proper replication, we cannot reliably estimate factor interaction effects and, therefore, pooled the two- and three-way interaction terms, thereby overestimating the true residual. This statistical test allowed us to reliably investigate the effect of each individual factor.

\section{Results}

\section{FA composition of GD1 and $H$. hermesi}

The total fatty acid composition was significantly different between both species $(\mathrm{p}=0.0054)$, and homogeneity of multivariate dispersions was found ( $\mathrm{p}=0.1044)$. Relative values for all FAs, based upon the total FA 
content can be found in Table 1. Replicate samples from $H$. hermesi clustered together with a similarity of $>90 \%$ and $\mathrm{GD} 1_{\mathrm{p}}$ replicates clustered together with a similarity $>80 \%$ (Fig. 1). Total FA composition between both species was $68.65 \%$ similar. SIMPER revealed that MUFA C16:1 $\omega 7$ was present in significantly higher proportions ( $\mathrm{p}=0.0032)$ in $H$. hermesi $(23.56 \%)$ compared to GD1 $(9.07 \%)$ and was most important in explaining the dissimilarity $(23.11 \%)$ between both species. This analysis further revealed that a total of 17 FAs contributed to explain $>90 \%$ of the dissimilarity (Table 2 ).

Classifying each FA into their respective group (SFAs, MUFAs and PUFAs) showed that MUFAs were the most abundant class for both species followed by PUFAs and SFAs (Fig. 2). SFAs C13:0 and ante(iso)C17:0, and MUFA C15:1 $\omega 5$ were only observed in $\mathrm{GD} 1_{\mathrm{P}}$ (Table 1 ; Fig. 3a). However, C13:0 was only identified in one GD1 $1_{\mathrm{p}}$ sample in very low proportions (0.13\%). SFA C22:0, MUFAs

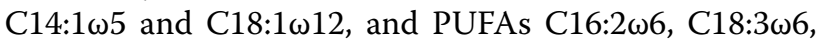
C20:3 $\omega 6$ and $\mathrm{C} 22: 6 \omega 3$ (DHA) were exclusively observed in $H$. hermesi (Fig. 3b, c). Of these uniquely observed FAs, DHA had the highest relative proportion (4.23 \%) of the total fatty acid content (Fig. 3c). The unsaturation index and SFA/UFA ratio of GD1 $1_{\mathrm{p}}$ was respectively lower $(\mathrm{p}=0.0021)$ and higher $(\mathrm{p}=0.0032)$ in $\mathrm{GD} 1_{\mathrm{P}}$ compared to $H$. hermesi (Table 3).

The relative amount of SFAs for H. hermesi $(8.85 \%)$ was significantly lower than the $28.43 \%$ for $G D 1_{P}(p=0$. 0023). C16:0 was the dominant SFA (Fig. 3a) in both $\mathrm{GD}_{\mathrm{P}}(31.0 \%)$ and H. hermesi (42.5\%). In addition, SFA composition was significantly different between both species $(\mathrm{p}=0.0017)$. Except for $\mathrm{C} 13: 0(\mathrm{p}=0.40557)$, C15:0 ( $\mathrm{p}=0.26365)$ and ante(iso)C16:0 $(\mathrm{p}=0.05720)$ all SFAs were significantly different between both species ( $p$ values $<0.05$, Additional file 1: Table S1). C14:0 $(\mathrm{p}=0.0102)$ and ante(iso)C15:0 proportions $(\mathrm{p}=0.0023)$ were significantly higher in $G D 1_{p}$, while $C 16: 0, C 17: 0$, C18:0 and C20:0 were significantly higher in $H$. hermesi (Fig. 3a).

The low relative SFA proportion in $H$. hermesi was compensated by significantly higher MUFA- $(11.83 \%$, $\mathrm{p}=0.0030)$ and PUFA $(7.75 \%, \mathrm{p}=0.0392)$ proportions in comparison to GD1 ${ }_{\mathrm{P}}$ (Fig. 2). The MUFA composition in both species was dominated by $\mathrm{C} 16: 1 \omega 7$ and C18:1 $\omega 9$ (Fig. 3b) which were responsible for 67.1 and $79.9 \%$ of the total MUFA composition of GD1 $1_{\mathrm{P}}$ and $H$. hermesi, respectively. The MUFA composition was significantly different between both species $(\mathrm{p}=0.0387$ ).

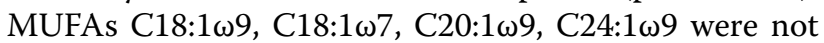
significantly different, while all other MUFAs were significantly different between both species ( $\mathrm{p}$ values $<0.05$, Additional file 1: Table S1). The MUFA composition of $H$. hermesi consisted of circa two times higher proportions of $\mathrm{C} 16: 1 \omega 7$ ( $\mathrm{p}=0.0102)$ compared to $\mathrm{GD} 1_{\mathrm{P}}$ (Fig. 3b), and was responsible for $40.2 \%$ of the MUFA dissimilarity between both species.

PUFA compositions were also significantly different between both species $(\mathrm{p}=0.0023)$ and were dominated by $\mathrm{C} 18: 2 \omega 6$ (Fig. 3c), responsible for $40.14 \%$ of the dissimilarity. The PUFA composition of $H$. hermesi showed a tendency towards HUFAs $(\geq 20$ carbons, $\geq 3$ double bonds) as was indicated by significantly higher HUFA values $(\mathrm{p}=0.0032)$ for $H$. hermesi (Table 3$)$. This was a result of higher EPA (C20:5 $\omega 3-E P A ; p=0.0017)$ pro-

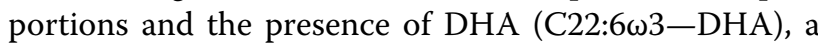
HUFA that was absent in GD1 $1_{\mathrm{P}}$ (Fig. 3c; Table 1). EPA and DHA were responsible for 11.72 and $9.29 \%$ of the PUFA dissimilarity between both species.

\section{FA composition of GD1 under different experimental conditions}

Similar to GD1 $1_{\mathrm{p}}$, SFAs had the lowest proportions in all experimental microcosms (Fig. 4; Table 1). SFA proportions were significantly affected by temperature $(\mathrm{p}=0.0368)$ resulting in $9.9-14.6 \%$ lower SFA proportions at $4{ }^{\circ} \mathrm{C}$ compared to $16^{\circ} \mathrm{C}$ (Fig. 4). Similar increases in UFA proportions were observed (Fig. 4) when temperature decreased $(\mathrm{p}=0.0069)$. Thus, the SFA/UFA ratio always significantly decreased $(\mathrm{p}=0.0074)$ with decreasing temperatures while the unsaturation index showed an inverse response $(\mathrm{p}=0.0444$, Table 3$)$. Increasing the salinity and adding sulphides did not have a significant effect on SFA proportions.

SFAs mainly consisted of (ante)isoform FAs and odd chain length FAs such as C15:0 and C17:0 (Fig. 5a) and the most abundant MUFAs were $\mathrm{C} 16: 1 \omega 7$ and $\mathrm{C} 18: 1 \omega 7$ (Fig. 5b). The effect of varying abiotic factors did not reveal any discernible trend in SFA and MUFA composition. PUFA compositions were very similar and highly

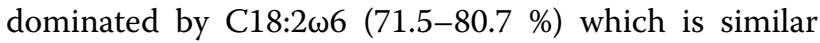
to $\mathrm{GD} 1_{\mathrm{P}}(67.4 \%)$ and $H$. hermesi $(59.3 \%)$. The PUFA composition (Fig. 5c) of experimental nematodes lacked $\mathrm{C} 18: 3 \omega 3$, compared to $\mathrm{GD} 1_{\mathrm{P}}$, DHA was not observed in the experimental nematodes and only trace amounts of EPA $(<1 \%)$ were present.

\section{FA composition of E. coli}

The most abundant fatty acids for the $E$. coli food source were SFAs $(93.5 \%)$ and no PUFAs could be identified (Table 1). SFA composition was similar to experimental nematodes (Fig. 5a) and was dominated by (ante) isoC15:0 (37.3 \%) and C16:0 (29.4 \%). Meanwhile, the composition of the MUFAs was very different from experimental GD1 nematodes (Fig. 5b) and consisted of $\mathrm{C} 16: 1 \omega 7$ (32.0\%), $\mathrm{C} 18: 1 \omega 9$ (51.1 \%) and $\mathrm{C} 18: 1 \omega 7$ (16.8\%). 
Table 1 Relative fatty acid proportions (\%), with respect to the total amount of FAs, of GD1 (Western Scheldt) and $H$. hermesi (Håkon Mosby mud volcano), GD1 under varying experimental conditions and of $E$. coli

\begin{tabular}{|c|c|c|c|c|c|c|c|c|c|c|c|}
\hline & \multicolumn{2}{|c|}{$\begin{array}{l}\text { Sampled for their } \\
\text { original habitat }\end{array}$} & \multicolumn{8}{|c|}{ GD1 under different experimental culture conditions } & \multirow{2}{*}{$\begin{array}{l}\text { Food } \\
\text { source } \\
\text { E. coli }\end{array}$} \\
\hline & GD1 $1_{p}$ & $\begin{array}{l}\text { H. } \\
\text { hermesi }\end{array}$ & $\begin{array}{l}25- \\
16^{\circ} \mathrm{C}- \\
\text { NoS }\end{array}$ & $\begin{array}{l}25-4^{\circ} \mathrm{C}- \\
\text { NoS }\end{array}$ & $\begin{array}{l}25- \\
16^{\circ} \mathrm{C}-\mathrm{S}\end{array}$ & $25-4^{\circ} \mathrm{C}-\mathrm{S}$ & $\begin{array}{l}34- \\
16^{\circ} \mathrm{C}- \\
\text { NoS }\end{array}$ & $\begin{array}{l}34-4^{\circ} \mathrm{C}- \\
\text { NoS }\end{array}$ & $\begin{array}{l}34- \\
16^{\circ} \mathrm{C}-\mathrm{S}\end{array}$ & $34-4^{\circ} \mathrm{C}-\mathrm{S}$ & \\
\hline $\mathrm{C} 12: 0$ & - & - & 0.71 & - & 0.34 & 0.31 & 0.32 & 0.25 & 0.49 & 0.31 & - \\
\hline C13:0 & $\begin{array}{l}0.04 \\
\quad( \pm 0.08)\end{array}$ & - & 0.69 & 1.20 & 1.43 & 0.78 & 1.58 & 0.59 & 0.50 & - & 1.82 \\
\hline C14:0 & $\begin{array}{l}4.82 \\
( \pm 1.27)\end{array}$ & $\begin{array}{l}0.68 \\
( \pm 0.06)\end{array}$ & 3.67 & 1.12 & 1.73 & 1.12 & 2.49 & 0.84 & 1.56 & 1.22 & 6.21 \\
\hline (ante)isoC15:0 & $\begin{array}{l}4.67 \\
( \pm 0.73)\end{array}$ & $\begin{array}{l}0.33 \\
( \pm 0.06)\end{array}$ & 8.64 & 10.71 & 12.53 & 7.30 & 13.65 & 5.53 & 4.38 & 2.95 & 34.71 \\
\hline C15:0 & $\begin{array}{l}0.63 \\
( \pm 0.06)\end{array}$ & $0.1( \pm 0.1)$ & 0.73 & 0.13 & - & 0.33 & 0.35 & 0.29 & 0.29 & 0.41 & 1.04 \\
\hline (ante)isoC 16:0 & $\begin{array}{l}0.89 \\
\quad( \pm 0.42)\end{array}$ & $\begin{array}{l}0.06 \\
( \pm 0.05)\end{array}$ & 0.34 & 0.66 & 1.35 & 0.77 & 0.50 & 0.65 & 1.06 & 0.11 & 8.21 \\
\hline C16:0 & $\begin{array}{l}9.12 \\
( \pm 1.07)\end{array}$ & $\begin{array}{l}3.76 \\
\quad( \pm 0.56)\end{array}$ & 8.03 & 2.01 & 3.22 & 2.88 & 3.77 & 2.53 & 3.78 & 4.82 & 27.33 \\
\hline (ante)isoC17:0 & $\begin{array}{l}3.12 \\
\quad( \pm 0.67)\end{array}$ & - & 6.05 & 3.83 & 4.29 & 2.71 & 4.57 & 2.60 & 2.25 & 3.46 & 9.04 \\
\hline C17:0 & $\begin{array}{l}0.73 \\
\quad( \pm 0.15)\end{array}$ & $\begin{array}{l}0.35 \\
\quad( \pm 0.02)\end{array}$ & 1.00 & 0.87 & 0.75 & 0.55 & 1.27 & 0.42 & 0.75 & 0.52 & 1.32 \\
\hline C18:0 & $\begin{array}{l}4.14 \\
\quad( \pm 0.16)\end{array}$ & $\begin{array}{l}3.11 \\
\quad( \pm 0.76)\end{array}$ & 3.64 & 1.79 & 2.75 & 1.69 & 1.89 & 2.05 & 3.93 & 2.17 & 3.82 \\
\hline$C 20: 0$ & $\begin{array}{l}0.28 \\
( \pm 0.03)\end{array}$ & $\begin{array}{l}0.39 \\
( \pm 0.05)\end{array}$ & - & - & - & - & - & - & - & - & - \\
\hline C22:0 & - & $\begin{array}{l}0.08 \\
( \pm 0.04)\end{array}$ & - & - & - & - & - & - & - & - & - \\
\hline$\sum S F A$ & $\begin{array}{l}28.43 \\
\quad( \pm 2.79)\end{array}$ & $\begin{array}{l}8.85 \\
\quad( \pm 1.33)\end{array}$ & 33.50 & 22.33 & 28.39 & 18.45 & 30.39 & 15.76 & 18.99 & 15.97 & 93.50 \\
\hline$C 14: 1 \omega 5$ & - & $\begin{array}{l}0.58 \\
\quad( \pm 0.09)\end{array}$ & - & - & - & - & - & - & - & - & - \\
\hline C15:1 $1 \omega 5$ & $\begin{array}{l}0.69 \\
\quad( \pm 0.09)\end{array}$ & - & 1.17 & 2.24 & 1.86 & 1.40 & 1.53 & 1.11 & 0.60 & 0.45 & 2.08 \\
\hline$C 16: 1 \omega 7$ & $\begin{array}{l}9.07 \\
( \pm 2.68)\end{array}$ & $\begin{array}{l}23.56 \\
\quad( \pm 1.35)\end{array}$ & 16.04 & 12.10 & 9.16 & 15.69 & 14.39 & 16.60 & 10.34 & 17.36 & - \\
\hline$C 17: 1 \omega 7$ & $\begin{array}{l}1.92 \\
( \pm 0.16)\end{array}$ & $\begin{array}{l}0.35 \\
\quad( \pm 0.13)\end{array}$ & 2.19 & 6.41 & 4.17 & 3.09 & 4.78 & 2.50 & 3.76 & 2.70 & 3.32 \\
\hline C18:1w12 & - & $\begin{array}{l}0.33 \\
( \pm 0.08)\end{array}$ & - & 0.66 & 0.43 & 0.30 & 0.17 & 0.68 & - & 0.35 & - \\
\hline C18:1 19 & $\begin{array}{l}19.21 \\
\quad( \pm 6)\end{array}$ & $\begin{array}{l}19.52 \\
\quad( \pm 0.46)\end{array}$ & 6.31 & 2.67 & 3.92 & 3.15 & 5.82 & 3.07 & 4.13 & 5.94 & 1.10 \\
\hline$C 18: 1 \omega 7$ & $\begin{array}{l}4.25 \\
( \pm 3.43)\end{array}$ & $\begin{array}{l}2.19 \\
\quad( \pm 0.27)\end{array}$ & 12.34 & 10.17 & 12.09 & 12.92 & 15.04 & 11.70 & 14.77 & 10.22 & - \\
\hline C20:1w9 & $\begin{array}{l}3.16 \\
( \pm 0.95)\end{array}$ & $\begin{array}{l}3.93 \\
( \pm 0.46)\end{array}$ & 0.66 & 1.23 & 1.60 & 1.60 & 0.74 & 1.79 & 2.10 & 1.12 & - \\
\hline$C 22: 1 \omega 9$ & $\begin{array}{l}2.32 \\
\quad( \pm 0.33)\end{array}$ & $\begin{array}{l}1.27 \\
( \pm 0.15)\end{array}$ & 1.03 & 0.65 & 0.57 & 0.36 & 0.63 & 0.98 & 0.55 & 0.53 & - \\
\hline$C 24: 1 \omega 9$ & $\begin{array}{l}1.46 \\
( \pm 0.74)\end{array}$ & $\begin{array}{l}2.18 \\
( \pm 0.21)\end{array}$ & 0.56 & 1.19 & 0.98 & 1.23 & 0.26 & 1.61 & 1.13 & 0.94 & - \\
\hline$\sum$ MUFA & $\begin{array}{l}42.71 \\
\quad( \pm 2.52)\end{array}$ & $\begin{array}{l}53.91 \\
\quad( \pm 1.60)\end{array}$ & 40.31 & 37.32 & 34.77 & 39.75 & 43.36 & 40.04 & 37.38 & 39.60 & 6.50 \\
\hline C16:2w6 & - & $\begin{array}{l}1.14 \\
\quad( \pm 0.2)\end{array}$ & - & - & - & - & - & - & - & - & - \\
\hline
\end{tabular}


Table 1 continued

\begin{tabular}{|c|c|c|c|c|c|c|c|c|c|c|c|}
\hline & $\begin{array}{l}\text { Sampled } \\
\text { original } h\end{array}$ & $\begin{array}{l}\text { for their } \\
\text { abitat }\end{array}$ & GD1 und & er different & experimen & al culture con & ditions & & & & $\begin{array}{l}\text { Food } \\
\text { source }\end{array}$ \\
\hline & $G D 1_{p}$ & $\begin{array}{l}H . \\
\text { hermesi }\end{array}$ & $\begin{array}{l}25- \\
16^{\circ} \mathrm{C}- \\
\text { NoS }\end{array}$ & $\begin{array}{l}25-4^{\circ} \mathrm{C}- \\
\text { NoS }\end{array}$ & $\begin{array}{l}25- \\
16^{\circ} \mathrm{C}-\mathrm{S}\end{array}$ & $25-4^{\circ} \mathrm{C}-\mathrm{S}$ & $\begin{array}{l}34- \\
16^{\circ} \mathrm{C}- \\
\text { NoS }\end{array}$ & $\begin{array}{l}34-4^{\circ} \mathrm{C}- \\
\text { NoS }\end{array}$ & $\begin{array}{l}34- \\
16^{\circ} \mathrm{C}-\mathrm{S}\end{array}$ & $34-4{ }^{\circ} \mathrm{C}-\mathrm{S}$ & E. coli \\
\hline C18:2w6 & $\begin{array}{l}19.4 \\
\quad( \pm 3.31)\end{array}$ & $\begin{array}{l}15.95 \\
\quad( \pm 0.45)\end{array}$ & 20.64 & 28.83 & 28.02 & 31.38 & 21.18 & 32.73 & 32.45 & 35.36 & - \\
\hline C18:3w3 & $\begin{array}{l}1.47 \\
( \pm 0.75)\end{array}$ & $\begin{array}{l}2.51 \\
\quad( \pm 0.55)\end{array}$ & - & - & - & - & - & - & - & - & - \\
\hline C18:3w6 & - & $\begin{array}{l}1.72 \\
( \pm 0.52)\end{array}$ & - & - & - & - & - & - & - & - & - \\
\hline$C 20: 2 \omega 6$ & $\begin{array}{l}4.33 \\
\quad( \pm 0.37)\end{array}$ & $\begin{array}{l}4.05 \\
\quad( \pm 0.16)\end{array}$ & 3.31 & 6.55 & 5.89 & 6.58 & 2.17 & 7.79 & 7.53 & 6.75 & - \\
\hline$c 20: 3 \omega 6$ & - & $\begin{array}{l}0.21 \\
\quad( \pm 0.02)\end{array}$ & - & - & - & - & - & - & - & - & - \\
\hline C20:4w6 & $\begin{array}{l}2.99 \\
\quad( \pm 0.38)\end{array}$ & $\begin{array}{l}3.53 \\
\quad( \pm 0.22)\end{array}$ & 2.23 & 4.59 & 2.94 & 3.63 & 2.77 & 3.44 & 3.24 & 2.32 & - \\
\hline C20:5 $203(E P A)$ & $\begin{array}{l}1.29 \\
( \pm 0.24)\end{array}$ & $\begin{array}{l}3.90 \\
\quad( \pm 0.23)\end{array}$ & - & 0.37 & - & 0.20 & 0.13 & 0.23 & 0.41 & - & - \\
\hline $\mathrm{C} 22: 6 \omega 3(\mathrm{DHA})$ & - & $\begin{array}{l}4.23 \\
( \pm 0.43)\end{array}$ & - & - & - & - & - & - & - & - & - \\
\hline$\sum$ PUFA & $\begin{array}{l}29.49 \\
\quad( \pm 3.97)\end{array}$ & $\begin{array}{l}37.24 \\
\quad( \pm 1.15)\end{array}$ & 26.19 & 40.35 & 36.84 & 41.80 & 26.24 & 44.20 & 43.63 & 44.43 & 0 \\
\hline
\end{tabular}

Mean values ( $(\mathrm{SD})$ of $G D 1_{p}$ and $H$. hermesi are represented. GD1 experimental labels consist of the salinity $(25$ or 34$)$-temperature $\left(4\right.$ and $\left.16^{\circ} \mathrm{C}\right)$-presence of sulphides is indicate by NoS (absence of sulphide) or $\mathrm{S}$ (presence of sulphide). Anteiso- and iso-form from a single fatty acid were summed and indicated by the addition of (ante)iso before each respective fatty acid

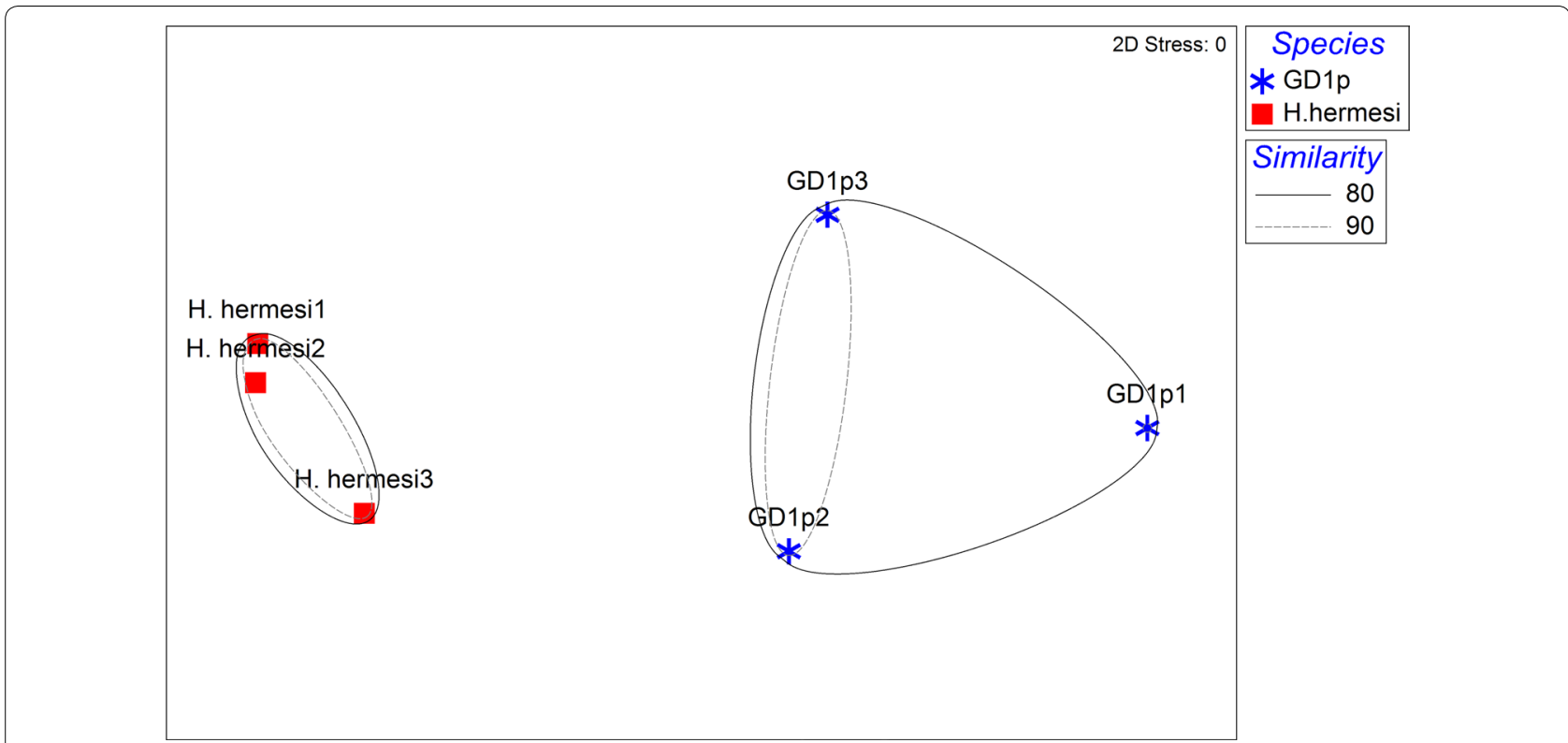

Fig. 1 Non-metric multidimensional scaling plot of all replicates of GD1 and $H$. hermesi based on Bray-Curtis similarities of relative proportions of all fatty acid. Contours show the similarities based on the cluster analysis. GD1p was sampled from the Western Scheldt estuary (intertidal), while $H$. hermesi was sampled from the Håkon Mosby mud volcano (HMMV)

\section{Discussion}

Fatty acid compositions of $H$. hermesi and GD1 $1_{p}$ indicate a homeoviscous adaptation to the deep-sea environment
Survival and successful reproduction of organisms relies on the ability to respond and adapt to the often varying conditions imposed by their environment. Fatty acid 
Table 2 Contribution (\%) of fatty acids to the total fatty acid content dissimilarity (up to $90 \%$ ) between GD1 p and $\boldsymbol{H}$. hermesi

\begin{tabular}{|c|c|c|}
\hline Fatty acid & Contribution (\%) & Cumulative (\%) \\
\hline$C 16: 1 \omega 7$ & 23.11 & 23.11 \\
\hline C16:0 & 8.55 & 31.65 \\
\hline C18:1w9 & 7.20 & 38.85 \\
\hline (ante)isoC15:0 & 6.92 & 45.77 \\
\hline $\mathrm{C} 22: 6 \omega 3(\mathrm{DHA})$ & 6.75 & 52.52 \\
\hline C14:0 & 6.60 & 59.12 \\
\hline C18:2w6 & 5.87 & 65.00 \\
\hline (ante)isoC 17:0 & 4.98 & 69.97 \\
\hline C20:5w3 (EPA) & 4.15 & 74.13 \\
\hline 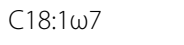 & 3.66 & 77.79 \\
\hline $\mathrm{C} 18: 3 \omega 6$ & 2.74 & 80.53 \\
\hline$C 17: 1 \omega 7$ & 2.50 & 83.04 \\
\hline $\mathrm{C} 16: 2 \omega 6$ & 1.82 & 84.86 \\
\hline C18:3w3 & 1.77 & 86.63 \\
\hline$C 22: 1 \omega 9$ & 1.66 & 88.29 \\
\hline C18:0 & 1.65 & 89.95 \\
\hline C20:1 $\omega 9$ & 1.35 & 91.29 \\
\hline
\end{tabular}

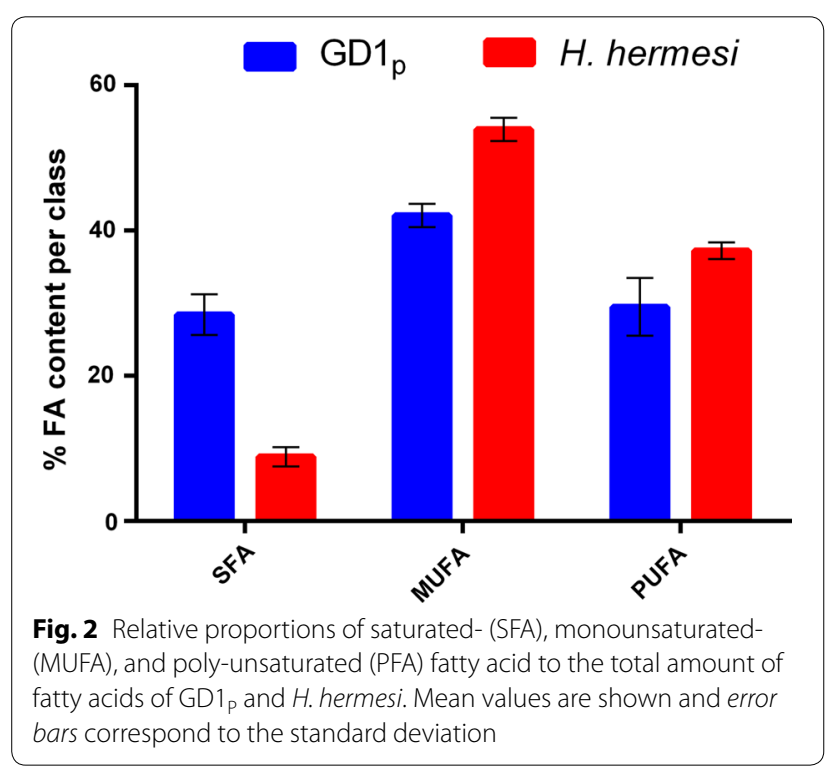

composition is known to rapidly (24-72 h) respond to changes in diet [66] and even daily/hourly fluctuations in FA composition have been observed previously [18, 23]. The barrier function of the cytoplasmic membrane is known to depend critically on the physical state of lipid bilayers [11], making it susceptible to environmental changes. The deep sea is a constant cold environment. When biological membranes are sufficiently cooled many biochemical reactions may be impaired which results in

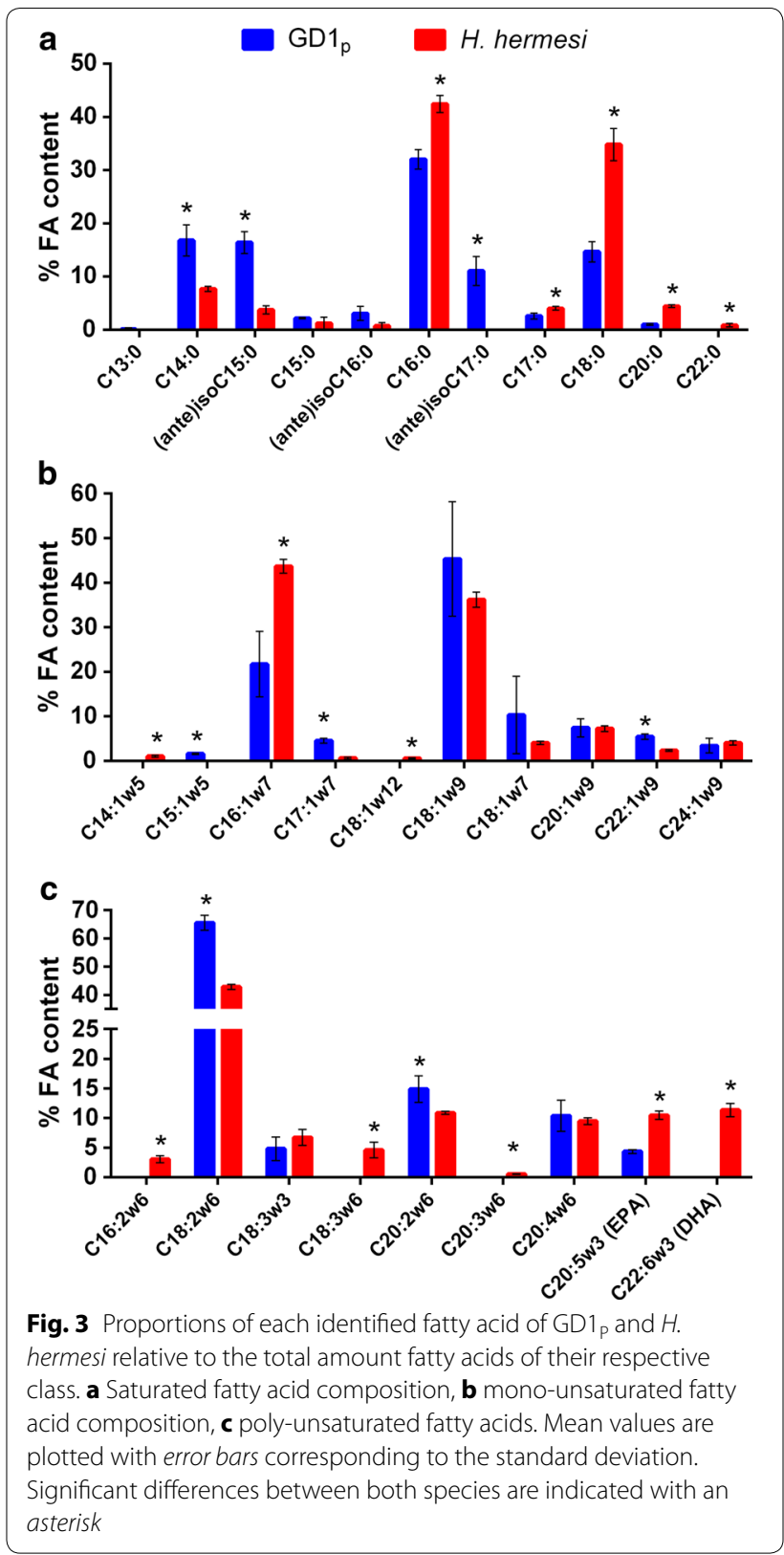

a decreased fluidity of lipids, a factor of primary importance to cell membrane function [30]. Increased MUFA proportions are most commonly reported as the agents involved in maintaining membrane order, with the addition of further double bonds having little effect on the phase transition properties and hence fluidity of the lipids [29]. Higher $16: 1 \omega 7$ proportions in $H$. hermesi could, therefore, be important in HVA to low temperatures.

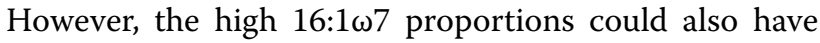
originated from the deep-sea HMMV bacteria Beggiatoa sp., the proposed food source for $H$. hermesi which is rich in 16:1 $\omega 7$ [72]. This MUFA has formerly been reported 
Table 3 SFA/UFA ratio, unsaturation index and highly unsaturated fatty acid (HUFA) proportion of GD1 (GD1 $1_{p}$ ) and $H$. hermesi sampled from their natural environment, GD1 under different conditions of salinity (25 and 34) temperature (16 and $4^{\circ} \mathrm{C}$ ), and presence of sulphide (NoS = absent and $S=$ presence), and of the $E$. coli food source

\begin{tabular}{llll}
\hline $\begin{array}{l}\text { Treatment- } \\
\text { species }\end{array}$ & SFA/UFA & Unsaturation index & HUFA \\
\hline GD1 1 p & $0.40( \pm 0.06)$ & $1.12( \pm 0.07)$ & $4.28( \pm 0.16)$ \\
H. hermesi & $0.10( \pm 0.02)$ & $1.68( \pm 0.03)$ & $11.78( \pm 0.88)$ \\
GD1 $\left(25-16^{\circ} \mathrm{C}-\right.$ & 0.50 & 0.97 & 8.52 \\
NoS $)$ & & & \\
$\mathrm{GD} 1\left(25-4^{\circ} \mathrm{C}-\mathrm{NoS}\right)$ & 0.29 & 1.28 & 12.30 \\
$\mathrm{GD} 1\left(25^{\circ}-16^{\circ} \mathrm{S}\right)$ & 0.40 & 1.14 & 7.97 \\
$\mathrm{GD} 1\left(25^{\circ}-4^{\circ} \mathrm{S}\right)$ & 0.23 & 1.31 & 9.17 \\
$\mathrm{GD1}\left(34-16^{\circ} \mathrm{C}-\right.$ & 0.44 & 1.02 & 11.02 \\
NoS $)$ & & & \\
$\mathrm{GD} 1\left(34-4^{\circ} \mathrm{C}-\mathrm{NoS}\right)$ & 0.19 & 1.36 & 8.31 \\
$\mathrm{GD} 1\left(34^{\circ}-16^{\circ} \mathrm{S}\right)$ & 0.23 & 1.32 & 8.37 \\
$\mathrm{GD} 1\left(34^{\circ}-4^{\circ} \mathrm{S}\right)$ & 0.19 & 1.33 & 5.22 \\
E. coli & 14.41 & 0.06 & 0 \\
\hline
\end{tabular}

SFA proportion of saturated fatty acid, UFA proportion of unsaturated fatty acids, HUFA proportion of highly unsaturated fatty acids defined as unsaturated fatty acids with a chain length $\geq 20$ carbon atoms and $\geq 3$ double bonds

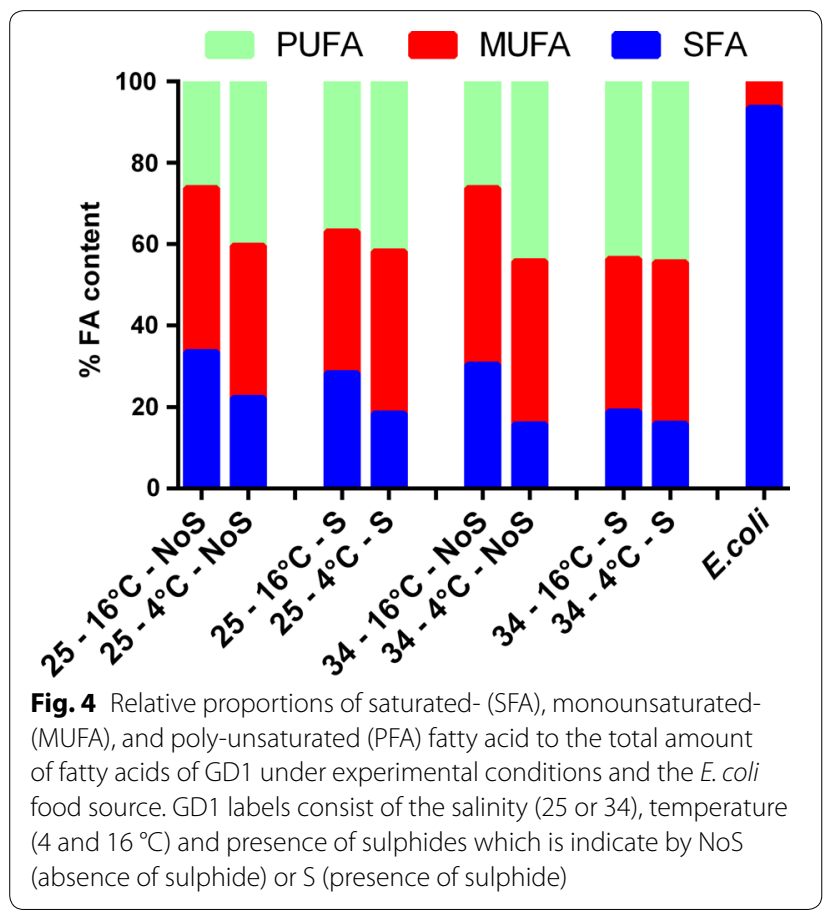

in Beggiatoa species from other cold seeps [20], suggesting that high 16:1 $\omega 7$ proportions might be important in HVA to cold-seep environments for Beggiatoa and in

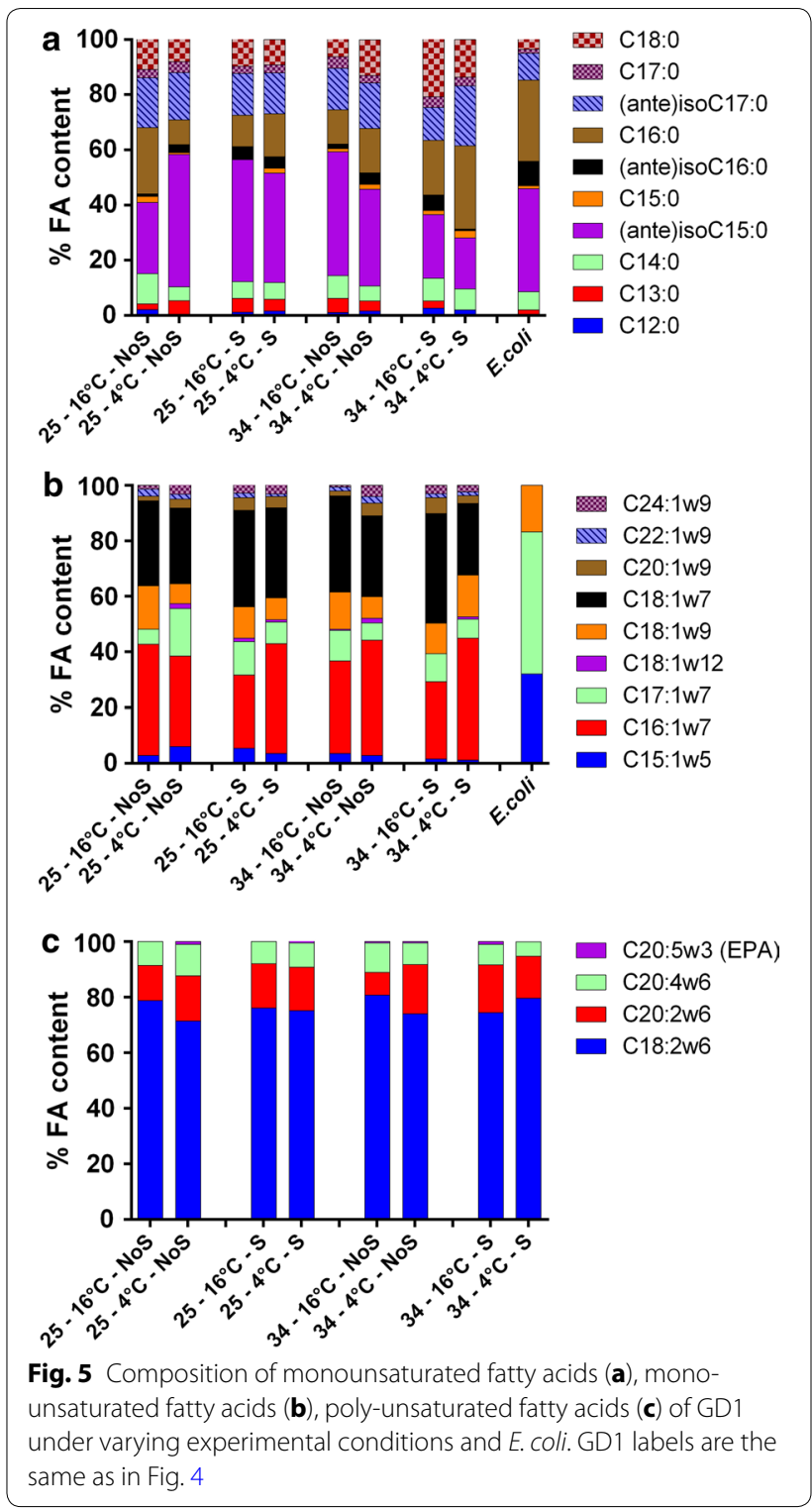

extension also for organisms feeding on the bacteria such as $H$. hermesi. Low temperatures can also result in an increase in PUFA proportions in nematodes [63], which can explain the increase in PUFA proportion observed in H. hermesi.

High hydrostatic pressure can have similar effect on FA composition as low temperatures, i.e. reduction in SFA proportion and an increase of UFA proportion $[6,13,14$, 82]. Lipids are known to be more compressible than proteins and are, therefore, in comparison more sensitive to pressure effects [78]. Accordingly, many deep-sea organisms modulate their membrane fluidity and composition in response to pressure [6]. Comparison of deep-sea and shallow-water fish revealed increased proportions of membrane fluidizing unsaturated fatty acids [9]. An 
increase in MUFAs and PUFAs and decrease in SFAs was also observed in vertically migrating marine planktonic copepods with increasing depth [52]. Our results revealed very similar effects in FA proportions, i.e. the proportion of saturated FAs in the deep-sea nematode $H$. hermesi is nearly $20 \%$ lower compared to its intertidal relative $\mathrm{GD} 1_{\mathrm{P}}$, which is compensated by higher amounts of MUFAs and PUFAs.

Fatty acid proportions of $H$. hermesi revealed the presence of the highly unsaturated fatty acid (HUFA) DHA

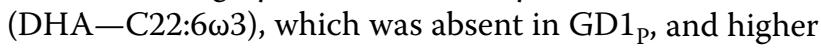
concentrations of the HUFA EPA (EPA-C20:5 $\omega 3$ ). Marine animals are known to contain high levels of these long-chain $\omega 3$ PUFAs $[2,65]$ and recent data suggest that also marine nematodes are rich in HUFAs [42] as was observed for $H$. hermesi. HUFAs are essential for normal functioning of cell membranes and membranebound enzyme systems, crucial regulators for animal cell membrane physiology [8]. Moreover, these HUFAs were hypothesized to important in HVA to high pressure and low temperatures [81]. DHA proportions also increased with depth in vertically migrating copepods suggesting its key role in maintaining membrane order in cold, high pressure conditions in the deep sea [52]. The absence of DHA in $\mathrm{GD}_{\mathrm{P}}$, contrasting to its presence in $H$. hermesi, therefore, suggests that DHA might be essential in HVA to a deep sea environment. Moreover, interaction between temperature and pressure on DHA proportions, consistent with homeoviscous adaption, has been recently reported [52].

Because both species are bacterivorous, one could expect DHA and EPA to originate from their respective food source. Even though DHA is uncommon in most bacteria, it is present in deep-sea bacteria, as is EPA [14, 83]. Studies on deep-sea bacteria [13, 50, 81] and growth experiments of bacterial cultures under high pressure [35] revealed the importance of increased proportions of the HUFA EPA (EPA-C20:5 03 ) under high pressure, which is in agreement with our results. However, a trophoecolocigal study on fatty acid compositions of Beggiatoa sps, the proposed food source of $H$. hermesi, revealed that HUFAs were absent [72]. Unlike most metazoans, nematodes are, however, able to biosynthesize HUFAs from acetate $[7,56]$ and from shorter fatty acid precursors [32]. Interestingly, a transcriptome comparison between $\mathrm{GD} 1_{\mathrm{P}}$ and $H$. hermesi [70] disclosed an overrepresentation of the KEGG pathway "fatty acid elongation" in $H$. hermesi. Given the absence of these EPA and DHA in the food source of $H$. hermesi [72], the nematode has most likely the ability to synthesize these HUFAs. EPA and DHA in addition can be assimilated into triglyceride forms and stored until they are required for incorporation in the membrane, beta-oxidation, signalizing activity, etc. [55, 79]. It, therefore, remains to be investigated what the primary function of these HUFAs is in $H$. hermesi.

It must be noted that other environmental differences might influence the FA composition of membranes. High salinities, for example, have an opposite effect on FA composition compared to high pressure and a low temperature [3, 38, 49]. A recent study revealed that increased salinities can also result in increased DHA and EPA proportions [21]. Moreover, synchronous effects of temperature, hydrostatic pressure, and salinity on FA composition have been previously observed [37]. Given the different (a)biotic features between both environments and the similar effect of temperature and pressure on the FA composition it is difficult to assess which abiotic factor is most responsible for the higher UFA proportion in $H$. hermesi. Therefore, we have experimentally tested the effect of different factors (temperature, salinity and sulphides) on the FA composition of GD1 to elucidate which factors significantly affected UFA proportions.

\section{FA composition of GD1 is affected by temperature, but not by salinity and sulphide changes}

Our results revealed that reduced growth temperatures result in greater proportions of unsaturated fatty acids, which is in accordance with previously observed temperature effects in nematodes [33]. However, no effect of salinity and sulphide was observed. This indicates that temperature is most likely the main factor responsible for the difference in UFA proportions between $G D 1_{P}$ and $H$. hermesi, while salinity and sulphides are of lesser importance. Our results further revealed that DHA was absent in all our experimental nematodes and only trace amounts of EPA have been found. This suggests that the high HUFA proportions of $H$. hermesi, in comparison to $\mathrm{GD} 1_{\mathrm{P}}$, is most likely a response to other factors such as pressure and less the result of differences in temperature, sulphides and salinities between both environments.

Our experimental data further showed high proportions of C15:0 and C17:0, and especially high (ante) isoform proportions of several FAs. Metazoa almost exclusively synthesize even-chain fatty acids [24] while bacteria are able to synthesize odd chain length, ante- and iso-forms of FAs, and branched fatty acids [36]. The presence of C17:0 and C15:0 has been previously observed in bacterivorous nematodes, be it in low amounts [32], in agreement with our study. It is, however, well established that the fatty acid composition of an organism most often reflect their diet $[45,57,72]$. Meanwhile, transfer up the food chain of C15:0 and C17:0 have been seen in copepods feeding on bacterivorous ciliates [19] and an unusually high amount (up to $50 \%$ ) of odd chain length FAs 
have been observed in the amphipod Pontoporeia femorata [51]. Both observations suggest that an organism is able to incorporate bacterial FAs. Odd chain length FAs and ante(iso) FAs are indeed present in the E. coli food source for GD1 and reflect the SFA composition of GD1 suggesting that the latter incorporates fatty acids from its food source to use in its membranes. In addition, absence of PUFAs in E. coli does clearly indicate and confirm that nematodes are able to biosynthesize long unsaturated fatty acids from shorter chain fatty acids as has previously been observed [59].

\section{Conclusion}

In this study we have shown that the fatty acid composition of closely related deep-sea and intertidal nematodes $\left(\mathrm{GD} 1_{\mathrm{p}}\right)$ clearly differs. The deep-sea nematode $H$. hermesi had higher unsaturated fatty acid proportions which could be attributed to the cold deep-sea environment. In addition, the saturated-, monounsaturated-, and poly-unsaturated fatty acid composition of both species is different. $H$. hermesi showed significantly higher 16:1 $\omega 7$ proportions, which might be important in HVA to cold-seep environments. The deep-sea nematode had elevated HUFAs such as EPA and DHA, suggesting that these HUFAs are important in HVA to the cold deep-sea environment as was previously reported for other deepsea organisms. Moreover, the lack of DHA and trace amounts of EPA in our experimental microcosms suggest that these HUFAs are a response to factors such as pressure and not a consequence of differences in temperature, salinity and sulphide concentrations. Subjecting GD1 to changing abiotic factors such as temperature, salinity and sulphides, revealed that only temperature significantly increased the unsaturated fatty acid proportions. This indicates that temperature is important in explaining differences in UFA proportions between $G D 1_{P}$ and $H$. hermesi. Finally, we were able to show that nematodes have the ability to synthesize polyunsaturated fatty acids which are not present in their food source.

\section{Additional file}

Additional file 1: Table S1 Closely related intertidal and deep-sea Halomonhystera species have distinct fatty acid compositions.

\footnotetext{
Authors' contributions

JVC and AV conceived the study; JVC performed the experiment, sampling and all the analyses and data handling. All authors contributed to data interpretation. JVC wrote the manuscript with significant input of AV. All authors read and approved the final manuscript.

\section{Author details}

${ }^{1}$ Research Group Marine Biology, Biology Department, Ghent University, Krijgslaan 281 S8, 9000 Ghent, Belgium. ${ }^{2}$ Center for Molecular Phylogenetics
}

and Evolution (CeMoFe), Ghent University, K.L. Ledeganckstraat 35, 9000 Ghent, Belgium.

\section{Acknowledgements}

We acknowledge chief scientist A. Boetius and project LOOME coordinator D. De Beer for the sampling opportunity during the RV Maria S. Merian campaign MSM 16/2. Special thanks to the captain and the crew of the RV 'Maria S. Merian', IFREMER (France). We thank Dirk Van Gansbeke for the fatty acid extractions and identifications. The data analysis of this research has benefitted from a statistical consult with Ghent University FIRE (Fostering Innovative Research based on Evidence). Additionally, we thank Bob Clarke (Plymouth marine laboratory) for statistical guidance in the use of PERMANOVA. This project was financed by the EU project HERMIONE (No. 226354), the Flemish Fund for Scientific Research (F.W.O) deep-sea project (No. 3G083512) and by the DFG for the Maria S. Merian cruise MSM 16/2.

\section{Competing interests}

The authors declare that they have no competing interests.

Received: 18 December 2015 Accepted: 14 July 2016

Published online: 08 September 2016

\section{References}

1. Abdulkadir S, Tsuchiya M. One-step method for quantitative and qualitative analysis of fatty acids in marine animal samples. J Exp Mar Biol Ecol. 2008;354(1):1-8.

2. Ackman RG. Fatty acids. In: Ackman RG, editor. Marine biogenic lipids, fats, and oils. Boca Raton: CRC Press; 1989. p. 103-37.

3. Alqarawi AA, Hashem A, Abd Allah EF, Alshahrani TS, Huqail AA. Effect of salinity on moisture content, pigment system, and lipid composition in Ephedra alata Decne. Acta Biol Hung. 2014;65(1):61-71.

4. Anderson MJ. PERMDISP: a FORTRAN computer program for permutation analysis of multivariate dispersions (for any two-factor ANOVA design) using permutation tests. Auckland: Department of Statistics, University of Auckland; 2004

5. Anderson MJ, Gorley RN, Clarke KR. PERMANOVA+ for PRIMER: guide to software and statistical methods. Plymouth: PRIMER-E Ltd.; 2008.

6. Bartlett DH. Pressure effects on in vivo microbial processes. BBA Protein Struct Mol Enzymol. 2002;1595(1-2):367-81.

7. Bolla R. Nematode energy metabolism. In: Zuckermann BM, editor. Nematodes as biological models, vol. 2. New York: Academic Press; 1980. p. 165-92.

8. Brett M, Müller-Navarra D. The role of highly unsaturated fatty acids in aquatic foodweb processes. Freshw Biol. 1997;38(3):483-99.

9. Cossins AR, Macdonald AG. The adaptation of biological membranes to temperature and pressure: fish from the deep and cold. J Bioenerg Biomembr. 1989;21(1):115-35.

10. Cossins AR, Macdonald AG. Homeoviscous adaptation under pressure 3 . The fatty-acid composition of liver mitochondrial phospholipids of deepsea fish. Biochim Biophys Acta. 1986;860(2):325-35.

11. Cronan JE, Gennis RB, Maloy SR. Cytoplasmic membrane. In: Neidhardt FC, Ingraham JL, Low KB, Magasanik B, Schaechter M, Umbarger HE, editors. Escherichia coli and Salmonella: cellular and molecular biology. Washington, D.C: American Society for Microbiology; 1987. p. 31-55.

12. De Troch M, Boeckx P, Cnudde C, Van Gansbeke D, Vanreusel A, Vincx M, Caramujo MJ. Bioconversion of fatty acids at the basis of marine food webs: insights from a compound-specific stable isotope analysis. Mar Ecol Prog Ser. 2012;465:53-67.

13. DeLong EF, Yayanos AA. Adaptation of the membrane lipids of a deep-sea bacterium to changes in hydrostatic pressure. Science. 1985;228(4703):1101-3.

14. DeLong EF, Yayanos AA. Biochemical function and ecological significance of novel bacterial lipids in deep-sea procaryotes. Appl Environ Microbiol. 1986;51(4):730-7.

15. Derycke S, Backeljau T, Vlaeminck C, Vierstraete A, Vanfleteren J, Vincx $\mathrm{M}$, Moens T. Spatiotemporal analysis of population genetic structure in Geomonhystera disjuncta (Nematoda, Monhysteridae) reveals high levels of molecular diversity. Mar Biol. 2007;151(5):1799-812. 
16. Drijber RA, Doran JW, Parkhurst AM, Lyon DJ. Changes in soil microbial community structure with tillage under long-term wheat-fallow management. Soil Biol Biochem. 2000;32(10):1419-30.

17. Duldhardt I, Gaebel J, Chrzanowski L, Nijenhuis I, Hartig C, Schauer F, Heipieper HJ. Adaptation of anaerobically grown Thauera aromatica, Geobacter sulfurreducens and Desulfococcus multivorans to organic solvents on the level of membrane fatty acid composition. Microb Biotechnol. 2010;3(2):201-9.

18. Dumm INTD, Dealaniz MJT, Brenner RR. Daily variations of the biosynthesis and composition of fatty-acids in rats fed on complete and fat-free diets. Lipids. 1984:19(2):91-5.

19. Ederington MC, Mcmanus GB, Harvey HR. Trophic transfer of fatty-acids, sterols, and a triterpenoid alcohol between bacteria, a ciliate, and the copepod Acartia tonsa. Limnol Oceanogr. 1995;40(5):860-7.

20. Elvert M, Boetius A, Knittel K, Jorgensen BB. Characterization of specific membrane fatty acids as chemotaxonomic markers for sulfate-reducing bacteria involved in anaerobic oxidation of methane. Geomicrobiol J. 2003:20(4):403-19.

21. Fonseca-Madrigal J, Pineda-Delgado D, Martinez-Palacios C, Rodriguez C, Tocher DR. Effect of salinity on the biosynthesis of $\mathrm{n}$-3 long-chain polyunsaturated fatty acids in silverside Chirostoma estor. Fish Physiol Biochem. 2012:38(4):1047-57.

22. Fonseca G, Derycke S, Moens T. Integrative taxonomy in two free-living nematode species complexes. Biol J Linn Soc. 2008;94(4):737-53.

23. Fozo EA, Quivey RG. Shifts in the membrane fatty acid profile of Streptococcus mutans enhance survival in acidic environments. Appl Environ Microbiol. 2004;70(2):929-36.

24. Fulco AJ. Fatty-acid metabolism in bacteria. Prog Lipid Res. 1983;22(2):133-60

25. Gerlach SA, Schrage M. Life cycles in marine meiobenthos-experiments at various temperatures with Monhystera disjuncta and Theristus pertenuis (Nematoda). Mar Biol. 1971;9(3):274-80.

26. Guckert JB, Antworth CP, Nichols PD, White DC. Phospholipid, ester-linked fatty-acid profiles as reproducible assays for changes in prokaryotic community structure of estuarine sediments. FEMS Microbiol Ecol. 1985;31(3):147-58

27. Guilini K, Veit-Kohler G, De Troch M, Van Gansbeke D, Vanreusel A. Latitudinal and temporal variability in the community structure and fatty acid composition of deep-sea nematodes in the Southern Ocean. Prog Oceanogr. 2013;110:80-92.

28. Guschina IA, Harwood JL. Mechanisms of temperature adaptation in poikilotherms. FEBS Lett. 2006;580(23):5477-83.

29. Hazel JR. Thermal adaptation in biological membranes: is homeoviscous adaptation the explanation? Annu Rev Physiol. 1995;57(1):19-42.

30. Hazel JR, Williams EE. The Role of alterations in membrane lipid-composition in enabling physiological adaptation of organisms to their physicalenvironment. Prog Lipid Res. 1990;29(3):167-227.

31. Heip C, Vincx M, Vranken G. The ecology of marine nematodes. Oceanogr Mar Biol. 1985;23:399-489.

32. Hutzell PA, Krusberg LR. Fatty acid compositions of Caenorhabditis elegans and C. briggsae. Comp Biochem Physiol Part B Comp Biochem. 1982:73(3):517-20.

33. Jagdale GB, Gordon R. Effect of temperature on the composition of fatty acids in total lipids and phospholipids of entomopathogenic nematodes. J Therm Biol. 1997;22(4-5):245-51.

34. Javed S, Bukhari SA, Ashraf MY, Mahmood S, Iftikhar T. Effect of salinity on growth, biochemical parameters and fatty acid composition in safflower (Carthamus tinctorius L.). Pak J Bot. 2014:46(4):1153-8.

35. Kamimura K, Fuse H, Takimura O, Yamaoka Y. Effects of growth pressure and temperature on fatty acid composition of a barotolerant deep-sea bacterium. Appl Environ Microbiol. 1993;59(3):924-6.

36. Kaneda T. Iso-fatty and anteiso-fatty acids in bacteria—biosynthesis, function, and taxonomic significance. Microbiol Rev. 1991;55(2):288-302.

37. Kaye JZ, Baross JA. Synchronous effects of temperature, hydrostatic pressure, and salinity on growth, phospholipid profiles, and protein patterns of four Halomonas species isolated from deep-sea hydrothermal-vent and sea surface environments. Appl Environ Microbiol. 2004;70(10):6220-9.

38. Kaye JZ, Marquez MC, Ventosa A, Baross JA. Halomonas neptunia sp. nov., Halomonas sulfidaeris sp. nov., Halomonas axialensis sp. nov. and Halomonas hydrothermalis sp. nov.: halophilic bacteria isolated from deep-sea hydrothermal-vent environments. Int J Syst Evol Microbiol. 2004;54(2):499-511.
39. Koštál V. Cell structural modifications in insects at low temperatures. In: Lee J, Lee Jr RE, editors. Low temperature biology of insects. New York: Cambridge University Press; 2010. p. 116-40.

40. Kreps EM. Lipids of cell membranes. Leningrad: Nauka; 1981.

41. Lambshead PJD. Marine nematode biodiversity. In: Chen ZX, Chen SY, Dickson DW, editors. Nematology: advances and perspectives, vol 1: Nematode morphology, physiology and ecology. Wallingford: International CABI; 2004. p. 436-67.

42. Leduc D, Probert PK. The effect of bacterivorous nematodes on detritus incorporation by macrofaunal detritivores: a study using stable isotope and fatty acid analyses. J Exp Mar Biol Ecol. 2009:371(2):130-9.

43. Levin LA. Ecology of cold seep sediments: interactions of fauna with flow, chemistry and microbes. Oceanogr Mar Biol Annu Rev. 2005;43:1-46.

44. Levins R. Evolution in changing environments: some theoretical explorations. Princeton: Princeton University Press; 1968.

45. MacAvoy SE, Macko SA, Joye SB. Fatty acid carbon isotope signatures in chemosynthetic mussels and tube worms from gulf of Mexico hydrocarbon seep communities. Chem Geol. 2002;185(1-2):1-8.

46. Moens T, Vincx M. On the cultivation of free-living marine and estuarine nematodes. Helgol Meeresunters. 1998;52(2):115-39.

47. Mokievsky VO, Filippova KA, Chesunov AV. Nematode fauna associated with detached kelp accumulations in the subtidal zone of the White Sea. Oceanology+. 2005:45(5):689-97.

48. Mrozik A, Piotrowska-Seget Z, Łabużek S. Changes in whole cell-derived fatty acids induced by naphthalene in bacteria from genus Pseudomonas. Microbiol Res. 2004;159(1):87-95.

49. Nichols DS, Olley J, Garda H, Brenner RR, McMeekin TA. Effect of temperature and salinity stress on growth and lipid composition of Shewanella gelidimarina. Appl Environ Microbiol. 2000;66(6):2422-9.

50. Nogi Y, Kato C, Horikoshi K. Taxonomic studies of deep-sea barophilic Shewanella strains and description of Shewanella violacea sp. nov. Arch Microbiol. 1998:170(5):331-8.

51. Paradis M, Ackman RG. Localization of a marine source of odd chainlength fatty-acids. 1. Amphipod Pontoporeia femorata (Kroyer). Lipids. 1976;11(12):863-70

52. Pond DW, Tarling GA, Mayor DJ. Hydrostatic pressure and temperature effects on the membranes of a seasonally migrating marine copepod. PLoS One. 2014;9(10):e111043.

53. Portnova $D$, Haflidason $H$, Todt $C$. Nematode species distribution patterns at the Nyegga pockmarks. In: 14th international meiofauna conference (FourtIMCo), Ghent, Belgium; 2010. p. 174

54. R Core Team. R: a language and environment for statistical computing. Vienna: R Foundation for Statistical Computing; 2013. http://www.Rproject.org/.

55. Reisner K. Physiological roles of fatty acids and endocannabinoids in the nematode Caenorhabditis elegans. Ph.D. dissertation, University of Easten Finland; 2012

56. Rothstein M, Gotz P. Biosynthesis of fatty acids in the free-living nematode, Turbatrix aceti. Arch Biochem Biophys. 1968;126(1):131-40

57. Ruess L, Haggblom MM, Zapata EJG, Dighton J. Fatty acids of fungi and nematodes-possible biomarkers in the soil food chain? Soil Biol Biochem. 2002;34(6):745-56.

58. Sauter EJ, Muyakshin SI, Charlou J-L, Schlüter M, Boetius A, Jerosch K, Damm E, Foucher J-P, Klages M. Methane discharge from a deep-sea submarine mud volcano into the upper water column by gas hydrate-coated methane bubbles. Earth Planet Sci Lett. 2006;243(3-4):354-65.

59. Schlechtriem C, Tocher DR, Dick JR, Becker K. Incorporation and metabolism of fatty acids by desaturation and elongation in the nematode, Panagrellus redivivus. Nematology. 2004;6:783-95.

60. Sikkema J, Debont JAM, Poolman B. Mechanisms of membrane toxicity of hydrocarbons. Microbiol Rev. 1995;59(2):201-22.

61. Sinensky M. Homeoviscous adaptation-a homeostatic process that regulates the viscosity of membrane lipids in Escherichia coli. Proc Natl Acad Sci USA. 1974:71(2):522-5.

62. Tahseen Q. Nematodes in aquatic environments: adaptations and survival strategies. Biodivers J. 2012;3(1):13-40.

63. Tanaka T, Ikita K, Ashida T, Motoyama Y, Yamaguchi Y, Satouchi K. Effects of growth temperature on the fatty acid composition of the free-living nematode Caenorhabditis elegans. Lipids. 1996;31(11):1173-8. 
64. Tchesunov AV, Portnova DA, Van Campenhout J. Description of two free-living nematode species of Halomonhystera disjuncta complex (Nematoda: Monhysterida) from two peculiar habitats in the sea. Helgol Mar Res. 2015:69:57-85.

65. Tocher DR. Metabolism and functions of lipids and fatty acids in teleost fish. Rev Fish Sci. 2003;11(2):107-84.

66. Turner JP, Rooker JR. Effect of dietary fatty acids on the body tissues of larval and juvenile cobia and their prey. J Exp Mar Biol Ecol. 2005;322(1):13-27.

67. Valentine RC, Valentine DL. Omega-3 fatty acids in cellular membranes: a unified concept. Prog Lipid Res. 2004;43(5):383-402.

68. Van Campenhout J, Derycke S, Moens T, Vanreusel A. Differences in life-histories refute ecological equivalence of cryptic species and provide clues to the origin of bathyal Halomonhystera (Nematoda). PLoS One. 2014;9(11):e111889.

69. Van Campenhout J, Derycke S, Tchesunov A, Portnova D, Vanreusel A. The Halomonhystera disjuncta population is homogeneous across the Håkon Mosby mud volcano (Barents Sea) but is genetically differentiated from its shallow-water relatives. J Zool Syst Evol Res. 2013;52(3):203-16.

70. Van Campenhout J, Vanreusel A, Van Belleghem S, Derycke S. Transcription, signaling receptor activity, oxidative phosphorylation, and fatty acid metabolism mediate the presence of closely related species in distinct intertidal and cold-seep habitats. Genome Biol Evol. 2016;8(1):51-69.

71. Van Gaever S, Moodley L, de Beer D, Vanreusel A. Meiobenthos at the Arctic Hakon Mosby Mud Volcano, with a parental-caring nematode thriving in sulphide-rich sediments. Mar Ecol Prog Ser. 2006;321:143-55.

72. Van Gaever S, Moodley L, Pasotti F, Houtekamer M, Middelburg JJ, Danovaro R, Vanreusel A. Trophic specialisation of metazoan meiofauna at the Håkon Mosby Mud Volcano: fatty acid biomarker isotope evidence. Mar Biol. 2009;156(6):1289-96.

73. Vettier A, Labbe C, Amerand A, Da Costa G, Le Rumeur E, Moisan C, Sebert $P$. Hydrostatic pressure effects on eel mitochondrial functioning and membrane fluidity. Undersea Hyperb Med. 2006;33(3):149-56.
74. Vranken G, Herman PMJ, Heip C. Studies of the life-history and energetics of marine and brackish-water nematodes: 1. Demography of Monhystera disjuncta at different temperature and feeding conditions. Oecologia. 1988;77(3):296-301.

75. Vranken G, Tire C, Heip C. Effect of temperature and food on hexavalent chromium toxicity to the marine nematode Monhystera disjuncta. Mar Environ Res. 1989;27(2):127-36.

76. Vranken G, Tire C, Heip C. The toxicity of paired metal mixtures to the nematode Monhystera disjuncta (Bastian, 1865). Mar Environ Res. 1988;26(3):161-79.

77. Vranken $G$, Vanderhaeghen $R$, Heip C. Toxicity of cadmium to free-living marine and brackish water nematodes (Monhystera microphthalma, Monhystera disjuncta, Pellioditis marina). Dis Aquat Organ. 1985;1(1):49-58.

78. Weber G, Drickamer HG. The effect of high-pressure upon proteins and other biomolecules. Q Rev Biophys. 1983;16(1):89-112.

79. Williams CM, Burdge G. Long-chain n-3 PUFA: plant v. marine sources. Proc Nutr Soc. 2006;65(1):42-50.

80. Yano Y, Nakayama A, Ishihara K, Saito H. Adaptive changes in membrane lipids of barophilic bacteria in response to changes in growth pressure. Appl Environ Microbiol. 1998;64(2):479-85.

81. Yano Y, Nakayama A, Yoshida K. Distribution of polyunsaturated fatty acids in bacteria present in intestines of deep-sea fish and shallow-sea poikilothermic animals. Appl Environ Microbiol. 1997;63(7):2572-7.

82. Yayanos AA, DeLong EF. Deep-sea bacterial fitness to environmental temperatures and pressures. In: Jannasch HW, Marquis RE, Zimmerman AM, editors. Current perspectives in high pressure biology. New York: Academic Press; 1987. p. 17-32.

83. Yazawa K, Araki K, Okazaki N, Watanabe K, Ishikawa C, Inoue A, Numao $\mathrm{N}$, Kondo K. Production of eicosapentaenoic acid by marine bacteria. J Biochem. 1988;103(1):5-7.

\section{Submit your next manuscript to BioMed Central and we will help you at every step:}

- We accept pre-submission inquiries

- Our selector tool helps you to find the most relevant journal

- We provide round the clock customer support

- Convenient online submission

- Thorough peer review

- Inclusion in PubMed and all major indexing services

- Maximum visibility for your research

Submit your manuscript at www.biomedcentral.com/submit
O Biomed Central 